\title{
Analisis Persepsi Konsumen
}

\author{
(Studi Kasus Molecular Mixology di Loewy, Jakarta) \\ Agung Gita Subakti, Darwin Tenironama, Ari Yuniarso \\ Bina Nusantara University \\ agsubakti@binus.edu, darwin.tenironama@gmail.com, ari_y@binus.edu
}

\begin{abstract}
Loewy is one of the restaurants and bars in Jakarta who serves drinks to the concept of molecular mixology. Molecular mixology itself developed in conjunction with the method of Molecular gastronomy which is a scientific study about gastronomy or the branch of science that studies the transformation of physiochemical on food during the cooking process and the phenomenon of knowledge as they consumed. However, molecular mixology is not as popular as molecular gastronomy where the general public still have yet to understand or even be aware of drinks made with this method. Therefore, the researchers want to do an analysis on consumer perceptions of product of molecular mixology in Loewy Jakarta. The research method used is descriptive methods. This is done to obtain a systematically and factual. By this study, it is expected to know the consumers' perception in Loewy Jakarta on beverage products made with the molecular mixology method.
\end{abstract}

Keywords — customers perception; molecular mixology; product; restaurant; bar

Abstrak-Loewy merupakan salah satu Restoran dan Bar di Jakarta yang menyajikan menu minuman dengan konsep molecular mixology. Molecular mixology sendiri berkembang bersamaan dengan metode Molecular gastronomy pada abad ke 20 dimana molecular gastronomy adalah studi ilmiah mengenai gastronomi atau lebih lengkapnya adalah cabang ilmu yang mempelajari transformasi fisiokimiawi dari bahan pangan selama proses memasak dan fenomena sensori saat mereka dikonsumsi. Namun pada perkembangannya, molecular mixology tidak sepopuler molecular gastronomy dimana masyarakat umum masih banyak yang belum memahami atau bahkan menyadari mengenai produk minuman yang dibuat dengan metode ini. Oleh karena itu, peneliti ingin melakukan analisa mengenai persepsi konsumen terhadap produk molecular mixology di Loewy Jakarta. Metode penelitian yang digunakan adalah metode deskriptifjenis survei, hal ini dilakukan untuk memperoleh gambaran secara sistematis dan faktual. Dengan penelitian ini diharapkan Loewy Jakarta dapat mengetahui persepsi konsumen terhadap produk minuman yang dibuat dengan metode molecular mixology .

Kata kunci_persepsi konsumen; molecular mixology; produk; restoran; bar

\section{PEndahuluan}

Dalam perkembangan bisnis di bidang jasa, terutama restoran dan bar terjadi perkembangan yang sangat pesat dan berkesinambungan. Setiap pelaku usaha di tiap kategori bisnis ini dituntut untuk memiliki kepekaan terhadap setiap perubahan yang terjadi dan menempatkan orientasi kepada kepuasan pelanggan sebagai tujuan utama. Tidak terkecuali pada jenis usaha dalam penyajian makanan dan minuman yang dimulai dari skala kecil seperti warung-warung dan kafe tenda; bisnis makanan berskala menengah seperti depot, rumah makan dan cafe; sampai dengan bisnis makanan yang berskala besar seperti restoran-restoran di hotel berbintang.

Para pelaku bisnis makanan dan minuman ditantang untuk menciptakan suatu diferensiasi unik dan positioning yang jelas sehingga konsumen dapat membedakan jenis usaha ini dengan para pesaingnya. Para pelaku bisnis harus menyiapkan strategi agar dapat menyenangkan hati dan membangun rasa antusiasme konsumen menjadi suatu pengalaman di dalam mengkonsumsi produk dan jasa, sehingga akan membuat mereka terkesan. Oleh karena itu diperlukan sebuah paradigma untuk menggeser sebuah pemikiran tradisional dalam kategori bisnis makanan dan minuman khususnya restoran, yang sebelumnya hanya menyediakan menu hidangan makanan dan minuman saja menjadi sebuah konsep modern yang menawarkan suatu pengalaman tak terlupakan.

Perkembangan produk pun berlangsung dengan pesat. Dari sisi makanan banyak restoran yang mulai menyajikan bentuk makanan dengan menggunakan proses yang dinamakan molecular gastronomy. Hal yang dilakukan beberapa restoran seperti Teatro Gastroteque dan Namaz untuk memberikan sensasi atau pengalaman baru. Di sisi lain, perkembangan mixology di Bar tidak semaju perkembangan dalam bidang proses pembuatan makanan. Walaupun di beberapa Bar sudah menyajikan minuman dengan konsep yang dinamakan molecular mixology. Namun sepertinya tidak banyak Bar yang menyajikan minuman dengan metode serupa. Hal ini yang menyebabkan 
banyaknya konsumen yang belum begitu memahami mengenai molecular mixology dan bagaimana cara menikmatinya.

Loewy merupakan Restoran dan Bar yang terletak di Oakwood Premier Cozmo Jakarta jalan Lingkar Mega Kuningan E42. No 1. Restoran ini menyajikan menu makanan dan minuman yang cukup beragam. Loewy menyajikan menu Breakfast dan Brunch untuk konsumennya dengan pilihan makanan yang bervariasi mulai dari makanan Indonesia, Asia hingga Eropa. Dari produk minuman, Loewy menyajikan wine dengan pilihan wine yang bervariasi, dijual perbotol dan per gelas, dari old world wine hingga new world wine. Dari jenis minuman lainnya Loewy menyajikan pilihan mocktail dan cocktail yang dibuat dengan metode klasik hingga metode molecular mixology.

Persepsi konsumen yang menikmati sajian konsep molecular mixology ini, menjadi penting untuk diketahui lebih lanjut. Berdasarkan hal tersebut, maka dibuat perumusan masalah sebagai berikut;

1. Bagaimana persepsi konsumen di Loewy, Jakarta

2. Bagaimana produk cocktail molecular mixology di Loewy, Jakarta

3. Bagaimana pengaruh persepsi konsumen terhadap produk cocktail molecular mixology di Loewy Restoran Jakarta.

Tujuan yang hendak dicapai dengan penelitian ini, adalah untuk mendapatkan sejumlahfakta/data penelitian yang akan diteliti dan dianalisis sehingga dapat digunakan sebagai dasar/acuan untuk mengetahui persepsi konsumen terhadap produk molecular mixology di Loewy, Jakarta.

\section{KAJIAN PUSTAKA}

\section{A. Produk}

Menurut (Kotler, 2002), produk adalah "segala sesuatu yang dapat ditawarkan ke pasar untuk mendapatkan perhatian, dibeli, dipergunakan, atau dikonsumsi dan yang dapat memuaskan keinginan atau kebutuhan." $(A$ Product is anything that can be offered to a market to satisfy a want or need). Menurut (Keegan, 1997), produk adalah "koleksi sifatsifat fisik, jasa, dan simbolik yangmenghasilkan kepuasan, atau manfaat, bagi seorang pengguna atau pembeli." Menurut (Simamora, 2002), definisi produk adalah kumpulan atribut yang memberikan nilai terhadap produk tergantung pada seberapa baik atribut itu dikelola. Berdasarkan beberapa definisi tersebut dapat ditarik kesimpulan bahwa produk adalah segala sesuatu yang dapat ditawarkan di pasar, yang nantinya akan dibeli oleh konsumen, dan dapat memberikan manfaat bagi konsumen, yang nantinya akan menghasilkan kepuasan tersendiri bagi pengguna produk tersebut.

Pada umumnya suatu perusahaan dalam merencanakan menawarkan produknya ke pasar perlu membedakan tingkatan produk. Menurut (Kotler, 2002) ada lima tingkatan produk yang perlu diperhatikan, yaitu:

a. Manfaat dasar (Core benefit) Yaitu manfaat yang diberikan oleh suatu produk yang dibeli konsumen agar dapat memenuhi keinginan dan kebutuhannya. Contoh manfaat dasar dari handphone adalah memberikan kemudahan dalam berkomunikasi dimana saja dan kapan saja.

b. Manfaat pasar (Generic product) Pemasar harus mengubah manfaat inti menjadi produk pasar.

c. Produk ekspektasi (Expected product) Pemasar menyiapkan suatu produk yang diharapkan. Produk yang sudah dilengkapi dengan atribut sehingga kondisi produk dapat diterima oleh konsumen yang membelinya. Contoh: tamu restoran yang mengharapkan tempat yang bersih, nyaman, dan peralatan makan yang bersih.

d. Produk yang ditingkatkan (Augment product) Pemasar menyiapkan suatu produk yang sudah ditingkatkan dan lebih baik lalu dipasarkan dengan pelayanan dan manfaat tambahan kepada para konsumen.

e. Produk potensial (Potential product) Perusahaan berusaha mencari berbagai caracara baru untuk memuaskan konsumen dan membedakan produk yang mereka hasilkan dengan yang lainnya.

\section{B. Klasifikasi Produk}

Sebagian besar, orang beranggapan bahwa produk hanya terdiri dari produk fisik saja, seperti mobil, rumah, buku, baju, dan sebagainya. Padahal jasa juga termasuk produk dan sering disebut produk jasa seperti: asuransi, pemangkas rambut, dan sebagainya. Menurut (Kotler, 2002), produk dapat diklarifikasikan sebagai berikut :

1. Daya tahan dan wujud (durability and tangibility)

a. Barang yang terpakai habis (non durable goods), yaitu barang berwujud yang biasanya dikonsumsi dalam satuatau beberapa kali penggunaan. Contohnya : sabun, garam, dan rokok. 
b. Barang tahan lama (durable goods), yaitu barang berwujud yang biasanya dapat digunakan berkali-kali. Contohnya : lemari es, kompor, mesin cuci, dan pakaian.

c. Jasa (service), yaitu barang yang tidak terlihat wujudnya. Jasa tidak dapat dipisahkan dan mudah habis. Akibatnya jasa biasanya memerlukan lebih banyak pengendalian kualitas.

2. Barang Konsumsi adalah barang yang dibeli konsumen untuk penggunaan dan kepuasan pribadi. Konsumen membeli sangat banyak macam barang. Berdasarkan kebiasaan berbelanja konsumen, maka barang konsumsi diklasifikasikan sebagai berikut :

a. Barang kebutuhan sehari-hari (convenience goods), adalah barangbarang yang biasanya sering dibeli konsumen, segera, dan dengan usaha minimum. Contohnya : meliputi produk rokok, sabun, dan surat kabar.

b. Barang belanjaan (shooping goods), adalah barang-barang yang karakteristiknya dibandingkan berdasarkan kesesuaian, kualitas, harga, dan gaya dalam proses pembeliannya. Contohnya meliputi perabotan rumah, pakaian, mobil bekas, dan peralatan rumah tangga.

c. Barang khusus (speciality goods), adalah barang yang berkarakter unik dan atau berorientasi kepada mereknya dimana mengakibatkan sekelompok konsumen bersedia melakukan usaha untuk membelinya.Seperti mobil mewah, rumah mewah, jam tangan mewah, dan sebagainya.

d. Barang yang tidak dicari (unsought goods), adalah barang yang tidak diketahui oleh banyak konsumen dan juga konsumen tidak terpikir untuk membelinya. Seperti asuransi, ensiklopedia dan sebagainya.

3. Barang Industri adalah barang yang digunakan untuk dijual kembali, menjalankan bisnis atau untuk memproduksi barang dan jasa lainnya. Barang-barang industri dibedakan menjadi:

a. Bahan baku dan suku cadang (material and part), adalah barang yang sepenuhnya masuk ke produk manufaktur. Barang-barang tersebut antara lain barang mentah atau bahan baku dan suku cadang manufaktur. b. Barang modal (capital items), adalah barang tahan lama yang memudahkan pengembangan atau pengolahan produk akhir. Seperti gudang dan mesin cetak.

c. Perlengkapan dan jasa bisnis (supplies and business service), adalah barang dan jasa yang tidak tahan lama yang membantu pengembangan atau pengolahan produk akhir. Barang perlengkapan dibagi menjadi barang operasional dan alat reparasi.

\section{Atribut-Atribut Produk}

Pengembangan suatu produk mengharuskan sebuah perusahaan menetapkan manfaatmanfaat apa saja yang diberikan oleh suatu produk tersebut. Manfaat itu dikomunikasikan dan dipenuhi oleh atribut produk yang berwujud seperti mutu, ciri, dan desain. Menurut (Kotler, 2002), atribut produk terdiri dari lima bagian, antara lain:

1. Mutu produk (Product Quality)

Dalam mengembangkan sebuah produk, produsen harus menemukan tingkat mutu yang akan mendukung posisi itu dalam pasar. Mutu produk menunjukkan kemampuan sebuah produk untuk menjalankan fungsinya. Termasuk didalamnya tahan lama, kehandalan, ketelitian, kemudahan pengoperasian, dan perbaikan.

2. Ciri atau gaya produk (Product Features) Ciri produk bagi suatu pemasaran dapat merupakan salah satu cara untuk memenangkan persaingan karena dalam hal ini ciri atau gaya produk menjadi suatu alat guna yang membedakan produk perusahaan dengan pesaing.

3. Desain produk

Desain produk dimaksudkan untuk menyelaraskan performa dari suatu produk dan fungsi dari produk tersebut, sehingga baik mutu dan ciri dari suatu produk dapat ditonjolkan tanpa mengganggu satu sama lain.

4. Sifat-sifat produk

Alat bersaing untuk membedakan produk dari produk pesaing. Sifat-sifat produk merupakan wujud yang diliat oleh konsumendan diperlukan untuk memenuhi keinginannya.suatu produk dapat ditawarkan dengan berbagai sifat, yaitu :

a. Model adalah pola akan sifat yang dimiliki produk yang dibuat atau dihasilkan

b. Sifat yang bernilai tinggi adalah sifat yang dimilikiproduk dan mempunyai 
nilai tersendiri yang membuat produk tersebut unggul

5. Rangsangan produk

Konsep yang lebih luas ketimbang gaya. Rangsangan merupakan suatu konsep tentang stimulan disamping penampilannya yaitu mengenai harga. Dengan adanya atribut-atribut diatas yang melekat pada suatu produk, maka digunakan untuk menilai konsumen yang menggunakan produk tersebut.

\section{Kekhasan Produk}

Kekhasan produk merupakan usaha perusahaan untuk membedakan produknya dari produk-produk pesaing dengan cara membuat produknya lebih menarik (Kotler, 2002). Kekhasan produk pada dasarnya atribut produk yang membedakannya dari produk sejenis, sehingga konsumen langsung dapat mengenali begitu melihatnya.

Molecular mixology adalah praktik khusus untuk mencampur minuman dengan menggunakan analisis dan teknik yang ditemukan dalam sains untuk memahami dan bereksperimen dengan bahan cocktail pada tingkat molekuler. Terinspirasi oleh praktik molecular gastronomy (yang bekerja dengan cara yang sama dengan makanan), praktik ini telah menjadi studi populer banyak ahli minuman. Tujuannya adalah untuk memanipulasi keadaan materi untuk menciptakan rasa, rasa, tekstur dan visual baru yang meningkatkan minuman dan membuat pengalaman pelanggan menjadi lebih menarik. Teknik pencampuran moleculer yang populer mencakup penggunaan busa, nitrogen cair, gel, kabut, panas, cairan pemadatan, dan lain-lain. Ada beberapa metode yang dilakukan, diantaranya adalah:

\section{SPHERIFICATION:}

Encapsulate flavors into bubbles that burst in your mouth: ini adalah satu bentuk metode dimana cairan dibuat sedemikian rupa sehingga berada didalam sphere atau gel berbentuk bola. Seperti halnya meminum alkohol namun dalam gel yang berbentuk bola bisa berbentuk bola besar maupun bola kecil kecil.

\section{EMULSIFICATION:}

Create colorful foams that intensify aromas: ini adalah satu bentuk metode dimana cairan tersebut akan berbentuk foam atau buih dengan banyak busa kecil. Biasanya untuk cocktail dengan konsep layering atau dibuat berlapis.

\section{GELIFICATION:}

Sculpt flavors into tasty pearls, raviolis or spaghettis: alkohol dibentuk seperti pasta atau mie yang memanjang.

\section{SUSPENSION:}

Create a floating effect of suspended fruits or molecular caviar: yaitu menciptakan efek seolah-olah dalam cocktail terdapat buah yang menggantung didalamnya (Molecular mixology Overview , 2014)

\section{E. Persepsi Konsumen}

Persepsi adalah suatu proses dimana individu mengorganisasikan dan menginterpretasikan kesan sensorik mereka untuk memberi arti pada lingkungan mereka. Apabila seseorang sudah memiliki motivasi, maka orang tersebut sudah siap untuk bertindak. Tindakan yang diambil ini akan dipengaruhi oleh persepsi pada situasi yang dihadapinya. Dua orang dengan motivasi dan tujuan yang sama mungkin bertindak secara berbeda karena mereka berada dalam situasi yang berbeda (Stephen Robbin, 2003:88). Persepsi sesorang terhadap sesuatu objek tidak berdiri sendiri akan tetapi dipengaruhi oleh beberapa faktor baik dari dalam maupun dari luar dirinya. Adapun menurut Zamroni (2006) faktor-faktor yang mempengaruhi persepsi diantaranya adalah :

1. Motif

Merupakan faktor internal yang dapat merangsang perhatian. Adanya motif dapat menyebabkan munculnya keinginan individu melakukan sesuatu atau sebaliknya.

2. Kesediaan dan Harapan

Dalam menentukan mana yang akan dipilih untuk di terima selanjutnya bagaimana pesan yang dipilih itu akan ditata dan di interprestasi.

3. Intensitas Rangsangan

Kuat lemahnya rangsangan yang diterima akan sangat berpengaruh bagi individu

4. Pengulangan

Suatu rangsangan yang muncul atau terjadi secara berulang-ulang akan menarik perhatian sebelum mencapai titik jenuh. Menurut Zamroni (2006), faktor-faktor yang mempengaruhi persepsi yaitu :

a. Stimulus yang kuat

b. Fisiologi atau Psikologi

Jika sistem fisiologi terganggu maka akan berpengaruh dalam persepsi seseorang. Sedangkan psikologis mencakup pengalaman, perasaan, kemampuan berpikir dan sebagainya, 
juga akan berpengaruh bagi seseorang dalam memberi persepsi.

\section{c. Lingkungan}

Situasi yang melatarbelakangi stimulus juga mempengaruhi persepsi

Faktor-faktor yang mempengaruhi persepsi menurut Stephen Robins (2003: 255 ) adalah :

1. Pelaku Persepsi

Cara pandang individu dalam mencoba menafsirkan dan dipengaruhi oleh karakteristik pribadi dari pelaku individu.

2. Target Atau Objek

Karakteristik-karakteristik dari target yang akan diawali dapat mempengaruhi apa yang dipersepsikan.

3. Situasi

Unsur-unsur lingkungan mempengruhi persepsi seseorang unsur-unsur itu misalnya tempat, waktu, cahaya, panas, atau setiap jumlah faktor situasional.

\section{Metode PENELITIAN}

Objek dalam penelitian ini adalah pengunjung Loewy Restoran Jakarta. Penelitian ini dilakukan pada jangka waktu penelitian kurang dari satu tahun, maka metode penelitian yang digunakan adalah Cross Sectional Method. Menurut Husain Umar (2008:45) adalah pendekatan Cross Sectional, yaitu metode penelitian dengan cara mempelajari objek dalam kurung waktu tertentu (tidak berkesinambungan dalam jangka waktu panjang). Penelitian ini diteliti pada bulan Februari sampai November tahun 2017.

Penelitian mengenai presepsi produk merupakan penelitian deskriptif, metode ini bertujuan untuk menggambarkan sifat sesuatu yang tengah berlangsung pada saat penelitian dilakukan (Umar, 2004). Penelitian deskriptif ini mengambil sampel dari satu populasi dan menggunakan kuesioner sebagai alat pengumpulan data yang pokok. Penelitian ini dilakukan pada konsumen Loewy, jenis produk yang diteliti adalah cocktail yang disajikan dengan metode molecular mixology .

Metode pengumpulan data yang digunakan dalam penelitian ini adalah :

a. Kuesioner yaitu pengumpulan data dengan menyebarkan daftar pertanyaan tertulis kepada responden untuk diisi.

b. Wawancara yaitu suatu cara pengumpulan data dengan mengajukan pertanyaanpertanyaan secara langsung pada pihakpihak yang berkompeten dengan masalah yang diteliti.

Pelitian ini adalah non probability sampling yaitu dengan cara purposive sampling.
Pengambilan sampel non probability merupakan teknik sampel yang tidak memberikan peluang yang sama bagi semua elemen populasi untuk dipilih menjadi anggota sampel. Menurut (Umar, 2004), purposive sampling merupakan pemilihan sampel berdasarkan pada karakteristik tertentu yang dianggap mempunyai sangkut paut dengan karakteristik populasi yang sudah diketahui sebelumnya. Kriteria yang diajukan dalam dalam penelitian ini adalah konsumen Loewy yang datang dan memesan cocktail dengan metode molecular mixology. Keputusan pengambilan sampel harus mempertimbangkan desain sampel dan ukuran sampel. Roscoe dalam (Sekaran, 2006) menyatakan bahwa ukuran sampel lebih dari 30 dan kurang dari 500 adalah tepat untuk kebanyakan penelitian. Pada penelitian ini jumlah responden yang diambil sebanyak 90 responden dikarenakan jumlah tersebut telah melebihi batas terkecil dari pendapat Roscoe.

\section{A. Kerangka Penelitian}

Berdasarkan perumusan masalah penelitian, maka kerangka penelitian sebagai berikut:

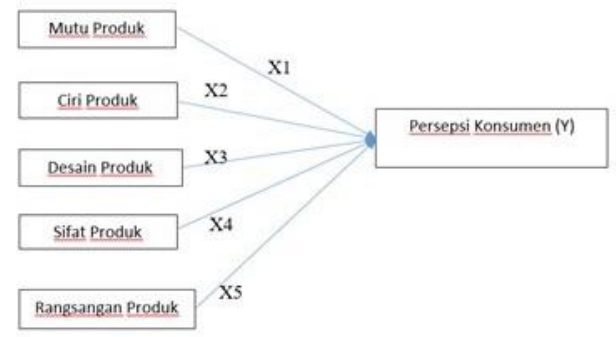

GAMBAR 1. KeRANGKA PENELITIAN

B. Hipotesis

1. Ho $: \rho=0$, tidak ada pengaruh dari Mutu Produk (X1), Ciri Produk (X2), Desain Produk (X3), Sifat Produk (X4) dan Rangsangan Produk (X5) terhadap variabel Persepsi Konsumen (Y).

2. Ha $: \rho \neq 0$, terdapat pengaruh yang signifikan dari Mutu Produk (X1), Ciri Produk (X2), Desain Produk (X3), Sifat Produk (X4) dan Rangsangan Produk (X5) terhadap variabel Persepsi Konsumen (Y).

\section{HASIL PENELITIAN DAN PEMBaHASAN}

\section{A. Pengujian Hipotesis secara Simultan}

Uji $F$ digunakan untuk mengetahui pengaruh keseluruhan variabel bebas terhadap variabel terikat. Berikut output ANOVA seperti yang ditunjukkan pada Tabel 1. 
TABEL 1. OUTPUT ANOVA

\begin{tabular}{|c|c|c|c|c|c|c|}
\hline \multicolumn{7}{|c|}{ ANOVA $^{a}$} \\
\hline & Model & Sum of Squares & df & Mean Square & $\mathrm{F}$ & Sig. \\
\hline \multirow{3}{*}{1} & Regression & 16.980 & 5 & 3.396 & 18.501 & $.000^{\mathrm{b}}$ \\
\hline & Residual & 16.704 & 91 & .184 & & \\
\hline & Total & 33.683 & 96 & & & \\
\hline
\end{tabular}

Sumber: Olahan Data Penelitian (2017)

Tabel 1 menunjukkan bahwa nilai $\mathrm{F}$ sebesar 18.501 dengan signifikansi 0,000 atau lebih kecil dibandingkan 0,05 , sehingga dapat disimpulkan bahwa Ho ditolak karena secara keseluruhan model fit dan bisa dilakukan penelitian selanjutnya. Hasil pengujian hipotesis tersebut menyatakan bahwa terdapat pengaruh antara produk terhadap persepsi konsumen.

Pengujian Hipotesis secara Parsial

Uji $\mathrm{t}$ berbeda dengan Uji $\mathrm{F}$, dimana Uji $\mathrm{t}$ digunakan untuk menguji pengaruh masingmasing variabel bebas terhadap variabel terikat. Berikut output koefisien regresi seperti yang ditunjukkan pada Tabel 2.

TABEL 2. KOEFISIEN REGRESI

\begin{tabular}{|c|c|c|c|c|c|c|c|c|}
\hline & \multicolumn{8}{|c|}{ Coefficients $^{\mathrm{a}}$} \\
\hline & \multicolumn{8}{|c|}{ Standardized } \\
\hline & & \multicolumn{2}{|c|}{ Unstandardized Coefficients } & \multicolumn{2}{|l|}{ Coefficients } & & \multicolumn{2}{|c|}{ Collinearity Statistics } \\
\hline & Model & B & Std. Error & Beta & $\mathrm{t}$ & Sig. & Tolerance & VIF \\
\hline 1 & (Constant) & .038 & .462 & & .082 & .935 & & \\
\hline & avrg.qual & .150 & .143 & .113 & 1.047 & .298 & .468 & 2.137 \\
\hline & avrgr.feat & .354 & .165 & .343 & 2.148 & .034 & .214 & 4.682 \\
\hline & avrg.desg & .333 & .119 & .263 & 2.793 & .006 & .615 & 1.627 \\
\hline & avrg.char & .119 & .114 & .132 & 1.044 & .299 & .342 & 2.924 \\
\hline & avrg.stim & .020 & .175 & .020 & .116 & .908 & .179 & 5.580 \\
\hline
\end{tabular}

Tabel 2 menunjukan bahwa koefisien regresi dari sub variabel mutu produk (quality) memiliki tingkat signifikansi sebesar 0,298, Sifat produk (Characteristic) memiliki tingkat signifikansi sebesar 0,299 dan rangsangan produk (Stimulation) memiliki tingkat signifikansi sebesar 0,908. Dari ketiga sub variabel tersebut tersebut dapat dikatakan signifikan karena kurang dari 0,05 yang artinya Ho ditolak. Sedangkan sub variabel Ciri Product (Feature) memiliki tingkat signifikansi sebesar 0,34, dan desain produk (design) memiliki tingkat signifikansi sebesar 0,006 dapat dikatakan tidak signifikan karena lebih dari 0,05 yang artinya Ho diterima.

Model Persamaan Regresi Berganda Persepsi Konsumen Terhadap Produk Cocktail Molecular mixology di Loewy Restoran Jakarta.Persamaan regresi berganda dapat dinyatakan sebagai berikut:

$\mathrm{Y}=\mathrm{a}+\mathrm{b} 1 \mathrm{X} 1+\mathrm{b} 2 \mathrm{X} 2+\mathrm{b} 3 \mathrm{X} 3+\mathrm{b} 4 \mathrm{X} 4+\mathrm{b} 5 \mathrm{X} 5$
Maka persamaan regresi berganda untuk persepsi konsumen terhadap produk cocktail molecular mixology di Loewy Restoran Jakarta dapat dinyatakan sebagai berikut:

$\mathrm{Y}=0,38+0,150 \mathrm{X} 1+0,354 \mathrm{X} 2+0,333 \mathrm{X} 3+$ $0,119 \mathrm{X} 4+0,20 \mathrm{X} 5$

Keterangan:

$\mathrm{Y}=$ Persepsi Konsumen

$\mathrm{X} 1=$ Mutu Produk

$\mathrm{X} 2$ = Ciri Produk

X3 = Desain Produk

X4 = Sifat Produk

X5 = Rangsangan Produk

Hasil menunjukan bahwa konstanta sebesar 0,38 menyatakan bahwa apabila mutu prouk, ciri produk, desain produk, sifat produk dan rangsangan produk diabaikan, maka nilai keputusan menggunakan meeting package yaitu sebesar 0,38. Koefisien regresi dari ciri produk sebesar 0,150, menyatakan bahwa setiap penambahan satu satuan maka nilai persepsi konsumen akan berubah sebesar $1,50 \%$, ciri produk sebesar 0,354, menyatakan bahwa 
setiap penambahan satu satuan maka nilai persepsi konsumen akan berubah sebesar $3,54 \%$, desain produk sebesar 0,333, menyatakan bahwa setiap penambahan satu satuan maka nilai persepsi konsumen akan berubah sebesar 3,33\%, Sifat produk sebesar 0,119 , menyatakan bahwa setiap penambahan satu satuan maka nilai persepsi konsumen akan berubah sebesar $1,19 \%$ dan rangsangan produk sebesar 0,20, menyatakan bahwa setiap penambahan satu satuan maka nilai persepsi konsumen akan berubah sebesar $2 \%$.

\section{KESIMPULAN DAN SARAN}

Hasil penelitian menunjukan bahwa produk cocktail molecular mixology berpengaruh signifikan terhadap persepsi konsumen Loewy Restoran. Dari kelima sub variabel produk yang terdiri dari mutu produk, Ciri produk, Desain Produk, Sifat produk, dan rangsangan produk terdapat tiga sub variabel yang berpengaruh signifikan yaitu mutu produk, sifat produk dan rangsangan produk. Bukan berarti ciri produk dan sifat produk tidak berpengaruh signifikan, akan tetapi dapat dikatakan signifikan namun dalam batas toleransi 90,1\%. Dalam hal ini dari keseluruhan persepsi konsumen terhadap produk cocktail molecular mixology di Loewy Restoran adalah positif.

\section{DAFTAR RUJUKAN}

Armawan, D. E. (2004). Perilaku Konsumen: Analisis Model Keputusan. Yogyakarta: Universitas Atmajaya.

Awaliyah, Ratih Fadlilah (2010). Analisis Pengaruh Persepsi Konsumen dan Bonus Dalam Kemasan Terhadap Keputusan Pembelian. Jakarta: Universitas Islam Negeri Syarif Hidayatulah

Basu Swastha, I. (2005). Manajemen Pemasaran Modern. Yogyakarta: Liberty.
H Nandan Ahmad Hidayat, S. M. (2015). Pengaruh persepsi terhadap keputusan pembelian melalui motivasi konsumen. Investasi Fakultas Ekonomi UnWir, 1(1), 19-35.

Husein, U. (2003). Riset Pemasaran dan Perilaku Konsumen. Jakarta: Gramedia Pustaka Umum.

Husein, U. (2004). Metode Penelitian untuk Skripsi dan Tesis Bisnis. Jakarta : Rajawali Press.

James F Engel, R. D. (1994). Perilaku Konsumen. Jakarta: Bainarupa Aksara.

Keegan, K. (1997). Manajemen Pemasaran Global. Jakarta: PT Prenhallindo. (2014). Diambil kembali dari Molecular Recipes: http://www.molecularrecipes.com/molecul ar-mixology-class/

Kotler, P. (2002). Manajemen Pemasaran Edisi Milenium Jilid 2. Jakarta: PT Prenhallindo

Oktavianus Taroreh, R. J. (2015). Pengaruh persepsi konsumen dan kepercayaan terhadap penggunaan jasa asuransi pada asuransi jasa manado. EMBA, 3(3), 312321.

Santoso, S. (2002). Menggunakan SPSS dan Excel untuk Mengukur Sikap dan Kepuasan Konsumen. Jakarta: PT Elex Media Komputindo.

Sekaran, U. (2006). Research Methods for Business, A Skill - Building Approach 3rd Edition. John Wiley \& Sons.

Simamora, B. (2002). Panduan Riset Perilaku Konsumen. Jakarta: PT Gramedia Pustaka Utama.

Sugiono. (2006). Metode Penelitian Administrasi. Bandung: CV Alfabeta. 
